\title{
Sob a máscara do colonial. Nascimento e "decadência" de uma vila no Brasil moderno: Vila Boa de Goiás no século XVIII ${ }^{1}$
}

Laurent VIDAL ${ }^{\bullet}$

\begin{abstract}
Resumo: Este artigo discute a emergência e a instalação da vida urbana em espaços periféricos do Brasil moderno. É fundamentado no caso de Vila Boa, situada no coração de região de minas de Goiás no início do século XVIII. Esta cidade de panelas de ouro (arraial), fundada em 1727, recebeu o status de vila em 1739, antes de se tornar capital da capitania de Goiás em 1749. A multiplicidade de períodos nesta cidade emergente e os intervalos entre eles permitem-nos estudar a originalidade das configurações espacial e social de Vila Boa durante o século XVIII. Entre o projeto da cidade (que tentam estampar marcos de poder no espaço local), a cidade no presente (com sua organização e outras negociações), e a cidade em espera (esperando pelas decisões do rei ou do vice-rei), Vila Boa encontra para si um caminho. Quando, com o decréscimo da produção de ouro, o "projeto colonial" perde muito de sua força, foi uma cidade mestiça que emergiu - sancionada pela palavra "declínio", a qual foi anexada a ela pelas autoridades coloniais.
\end{abstract}

Palavras-chave: Colônia; Fronteira; Vila; Poderes; Sociedade; Espera.

No dia 26 de maio de 1742, os oficiais municipais de Vila Boa dirigem-se, por escrito, ao rei de Portugal. Acabavam de anular a procissão de Corpus Christi (a festa do corpo de Deus) e de encarcerar quatro membros da confraria do Santo

\footnotetext{
- Centre de recherches en histoire internationale et Atlantique (CRHIA) - FLLASH - Université de La Rochelle - Université Paris 3 - Sorbonne Nouvelle - 17000 - La Rochelle - França.

E-mail: lucilia-siqueira@uol.com.br
}

HISTÓRIA, São Paulo, 28 (1): 2009 
Sacramento. E, exatamente por conhecerem a gravidade da decisão que haviam tomado, explicavam suas razões ao rei:

Uma hora inteira na presença do dito governador exortando-os a nos alugar os ornamentos e fizeram muito contra sua vontade e com efeito se fez a solenidade da festa como era de costume; porém com tanto murmúrio do povo e da mesma irmandade contra esta câmara [é] que temos tomado por determinação não fazer festa real ${ }^{2}$.

Os motivos desta discórdia? São os próprios membros da confraria que os apresentam ao rei alguns dias depois:

a câmara da mesma vila pretendia excluir o dito provedor do seu lugar imediato atrás do pálio em que costumava ir desde a criação desta mesma freguesia e nas suas procissões não pegassem os ditos irmãos nas varas do palio desde o altar-mor até as portas da igreja como costumavam.

E concluem: "ficou aquele senado cometendo uma escandalosa violência"." Esta cena acontece três anos depois da fundação de Vila Boa, primeiro povoado da região das Minas de Goiás. Todos os atores desta nova cidade tomaram parte das cerimônias de sua criação: os oficiais municipais, os membros da principal confraria de Vila Boa, o clero (o provedor da confraria não é outro senão o vigário), o governador e o povo. Ela se oferece ao historiador como reveladora da natureza maior da cidade no Brasil colonial - espaço de representação, de competição mesmo, entre poderes civis e religiosos, colonial e municipal, entre o povo e as elites. Por que é, em primeiro lugar, como uma cidade em projeto que é preciso compreender a "cidade colonial" brasileira. Ao instituir uma cidade o poder metropolitano se projeta no espaço colonial, ao mesmo tempo em que pretende projetar os valores fundamentais de uma ordem, dita colonial, no interior dos muros da cidade. Por outro lado, segundo um calendário bem regrado, a sociedade destas cidades também se projeta no espaço e no tempo: por meio de festas oficiais, de cerimônias, de encenações rituais, ela se 
permite ver como a expressão de um modelo ideal.

Mas poder-se-ia, mesmo assim, reduzir o conjunto do acontecimento urbano a esta dimensão intencional? Uma mudança de foco para observar a cidade no presente, não permitiria entrever um outro funcionamento social e espacial, menos abstrato, mais fluido, onde dominam negociações, adaptações e, até mesmo, disputas? Até onde o "modelo colonial" é capaz de constranger ou dominar o quotidiano dessas sociedades? Da mesma forma, é preciso considerar um outro aspecto que vem contrariar sua aplicação mecânica - a lentidão das correspondências administrativas. Vila Boa está situada nos confins do Brasil, distante mais de um mês do Rio de Janeiro ou da Bahia, os dois principais portos da colônia. E Lisboa está do outro lado do Atlântico. Consequentemente, não é raro que a resposta a uma solicitação feita ao rei possa demorar até um ano para chegar. Durante esse tempo, a vida se instala numa espécie de entre-deux (lugar intermediário) em que cada um dos protagonistas deve fazer face à incerteza, à espera de uma decisão distante, tão desejada quanto temida.

Dessa forma, a cena da procissão põe em evidência múltiplas temporalidades: aquela da cidade em projeto, procurando inscrever as marcas do poder no espaço urbano; aquela da vila no presente, com seus arranjos e negociações; e aquela da cidade à espera das decisões do rei. Todos estes tempos coexistem em Vila Boa, se interpenetram ou se ignoram, se superpõem ou entram em conflito. Tomar consciência da emergência e da instalação da vida urbana no Brasil moderno é, antes de tudo, apreender a multiplicidade dos tempos em curso na nascente cidade (quaisquer que sejam suas formas e estatutos jurídicos), bem como os seus deslocamentos, capazes de dar forma a configurações sociais originais, às vezes inesperadas. Ao apontar as distâncias entre a ambição da coroa em transpor um modelo ideal $e$ as possibilidades reais oferecidas pela situação concreta da região, considerando e realçando as necessárias adaptações, nós levantaremos, pouco a pouco, a máscara do "colonial" - este adjetivo ao qual recorrem 
muito facilmente os historiadores quando se trata de descrever a vida social no Brasil moderno.

Com efeito, no campo da historiografia da América portuguesa (mas, não somente aí, é evidente) o uso do adjetivo "colonial" reenvia, antes de mais nada, às especificidades da organização administrativa do território, bem como aos laços de dependência frente à metrópole. No Brasil, as cidades e, sobretudo, as cidades-portos, enquanto intermediárias desta ordem colonial, são estudadas sob este aspecto - como figura ou encarnação de uma ordem colonial: estudo do urbanismo e da arquitetura, das estruturas da administração municipal, das trocas comerciais, das grandes famílias e de suas ligações transatlânticas, das estruturas sociais ${ }^{4}$. No Dictionnaire de vocabulaire portugais et latin de Raphael Bluteau (publicado em 1712, em Coimbra), a palavra colonial é inexistente. Encontra-se ali o termo "colônia" (originário do latim), definido segundo uma dupla acepção: "Pessoas enviadas para uma terra recentemente descoberta ou conquistada, para povoá-la"; "a mesma terra assim povoada chama-se, igualmente, colônia". A palavra "colono" também se encontra presente, definida como "um dos fundadores de uma colônia". Segundo o Dictionnaire historique de la langue française Le Robert, o adjetivo colonial apenas aparece nas línguas latinas a partir de 1776, por empréstimo ao inglês colonial, que significa: "aquilo que se relaciona às colônias". É, finalmente, no momento em que as treze colônias, na América do Norte, denunciam o pacto que as liga à sua metrópole, que o adjetivo se impõe e se difunde, para distinguir e realçar justamente a diferença entre o que seria do domínio metropolitano e do domínio colonial - como se, juridicamente, se tratasse de entidades perfeitamente distintas. Por conseguinte, não parece ilegítimo questionar se alguns historiadores (notadamente nos trabalhos anteriores aos anos 1990), ao qualificar a priori de coloniais as práticas sociais ou especificidades urbanas, não supervalorizaram a rigidez em suas análises sobre as cidades existentes na colônia. Ao adotar o ponto de vista distante e normativo do poder metropolitano, projetando-o sobre o quotidiano daquelas sociedades, não 
teriam reconstruído artificialmente aquele universo urbano? Toda uma produção historiográfica recente convida justamente a repensar a "política colonial" de Portugal em relação ao Brasil no interior de uma connected history do império português, "conduzindo à formação de sociedades reguladas pela economia e por uma cultura política do Antigo Regime português"." Assim, o que está aqui em discussão é a própria pertinência da noção "política colonial"

Eis porque a noção de "projeto" ou de "projeto colonial" que utilizamos aqui para definir a "cidade colonial", reenvia não a uma política definida pela metrópole para o conjunto da colônia, mas à ambição, mais circunscrita e circunstancial, que alimentava Lisboa em relação à fundação de uma vila em particular. É, pois, através de redes com malhas variáveis, que precisamos apreender Vila Boa de Goiás em sua gênese: nos tempos breves, mas disputados de seu nascimento, nos tempos confusos de seus primeiros passos e nos tempos dilatados da instalação da vida social.

\section{A cidade em projeto: nascimento nas fronteiras}

Um dos argumentos utilizados pelos membros da confraria para justificar o lugar pertencente ao provedor na procissão consiste em reivindicar a legitimidade histórica da prática que lhe garantia tal posição. Com efeito, esta lhe teria sido confirmada "desde a criação da paróquia" em 1729, enquanto o corpo municipal (a câmara) "sendo criada" somente "em julho de $1739^{7 "}$. No centro desta defasagem cronológica, entre a criação da paróquia e a institucionalização do corpo municipal, teve lugar o nascimento político e religioso de Vila Boa. São estes diferentes tempos que, antes de mais nada, convém analisar. 


\section{Os tempos disputados do arraial}

Sobre estas margens da colônia, distante dos eixos de comunicação e dos grandes centros administrativos e comerciais, é antes de tudo o ouro que atrai e fixa os homens. Assim, explica, em 1755, o secretário do governo de Goiás, Ângelo dos Santos Cardoso, que as jazidas de ouro da região de Vila Boa foram descobertas pelo "explorador Bartolomeu Bueno da Silva, originário de São Paulo, de onde partiu, com sua tropa em $1722^{8}$ ". Munido de uma autorização real, concedida pelo governador ${ }^{9}$, que lhe permitia penetrar o sertão, Bueno organizou uma expedição (bandeira) composta de trinta e nove cavalos, dois religiosos bentos, um franciscano, cento e cinquenta e duas armas e vinte índios ${ }^{10}$. E o ouro que estes homens, os bandeirantes, perseguem incansavelmente é um ouro de aluvião. Foi durante a segunda expedição, em julho de 1726, que Bueno e seus homens realizaram as primeiras prospecções "no rio que passa no meio desta vila, pouco abundante em água, mas rico em ouro". Encontrando um filão particularmente promissor, Bueno ordenou a construção de um acampamento, um rancho, nas proximidades do rio Vermelho e, logo depois, em virtude das disposições do "Regimento dos superintendentes, guardas-mores e oficiais enviados às minas de ouro"11, informa ao governador sobre sua nova descoberta que, por sua vez, o comunica oficialmente ao rei ${ }^{12}$. Este lhe concede, então, através de carta com data de 29 de abril de 1727, os títulos de descobridor das minas dos Guayazes ${ }^{13}$, de guarda-mor das minas (encarregado da distribuição dos terrenos auríferos), de capitão-mor (grau mais elevado dos oficiais dos corpos de milícia ou das ordenanças) e os direitos de duas concessões de terras auríferas (datas minerais) ${ }^{14}$. O título de "descobridor das minas" conferia a Bartolomeu Bueno um poder quase discricionário sobre o conjunto da região, visto que controlava igualmente os direitos de passagem sobre os rios situados no caminho São Paulo-Goiás ${ }^{15}$. A notícia do descobrimento do ouro se espalha rapidamente e logo uma multidão heterogênea se dirige para estas terras ainda 
inexploradas, alguns atraídos pelas promessas de enriquecimento fácil, outros pela esperança de escapar da justiça ou de devedores. Quando redigia seu relatório para a Coroa em 1755, Ângelo dos Santos Cardoso não parece guardar nenhuma estima por estes primeiros ocupantes, em quem não vê senão vulgares aventureiros:

Eram Paulistas, misturados com emboabas (que assim chamam os filhos do reino), mas de tão ínfima qualidade, os do reino, que talvez não soubessem dizer de que freguesia eram, ou bancarroteiros, e dos sertões das Minas Gerais, de São Paulo e Cuiabá, que acossados de dívidas, como ainda hoje costumam, vem buscar os haveres que se manifestam mais mordernos; esta casta de gente foi a que sempre deu principio a estabelecimento de minas, e a que mais francamente as povoam [...]; mas como estes países têm a especialíssima qualidade de fazer verdadeiras as metamorfoses que fabulou a Antiguidade, converte estes pícaros, sem que faltem o uso das suas picardias, em senhores de grande consideração ${ }^{16}$.

Visando implantar os poderes conferidos pela Coroa e organizar a ocupação humana num espaço que já não poderia ser considerado um simples acampamento, Bueno funda então um arraial, espécie de povoação sem autonomia jurídica ou administrativa, submetida à tutela de uma vila - neste caso a de São Paulo. Ordena, assim, que seja erguida uma capela, no centro de uma de suas concessões. Instalada sobre uma ligeira elevação, pouco acima do rio Vermelho, dedicada à Santa Ana ou Sant'Anna, é a partir dela que vão se organizar as principais ruas daquele que, a partir de então, será o arraial de Sant'Anna.

A definição jurídica de um arraial não é fácil. Segundo Aroldo de Azevedo ${ }^{17}$, um arraial é um povoado que não pode ser comparado nem a um hameau francês, nem ao hamlet inglês, menos ainda ao casal português, e apenas poderia ser aproximado ao pueblo da América espanhola. Os povoados constituem as formas mais elementares de aglomerações urbanas. No caso de um arraial mineiro, o povoado nasce a partir da instalação, na forma de um acampamento, de uma "tropa 
itinerante", em torno da atividade de extração do ouro. Por outro lado, não possuindo nenhuma autonomia reconhecida, o arraial não pode ser considerado como uma primeira forma de municipalidade. É bem verdade que a Coroa não tem outro recurso senão recorrer a estes homens e seus seguidores para conquistar e povoar o enorme território da colônia, mas a instabilidade desta forma de povoamento é por demais evidente para que sejam atribuídos, a priori, direitos ao arraial.

Infelizmente, a documentação não é nem um pouco consistente para uma descrição mais clara dos primeiros tempos deste aglomerado mineiro ${ }^{18}$. Podemos, no entanto, constatar que, inicialmente, os poderes civil e religioso empreendem uma verdadeira queda de braço para afirmar suas pretensões ao controle dos homens e das almas naquele arraial. Pois, se a estruturação do espaço se faz em torno da capela de Sant'Anna, indicando o quanto a religião é um poderoso fator de estabilização das populações nas regiões mineiras, não é por isso, entretanto, que o poder civil abdica de toda a sua ambição. Bartolomeu Bueno desfruta, com efeito, do privilégio "e da fortuna de ser obedecido daqueles primitivos com unanimidade, fazendo o dito regente ao mesmo tempo as funções de general, ouvidor, e de juiz"19". Este homem "simples, ignorante", nomeia para os principais cargos civis e militares do arraial os membros de sua própria família, instaurando, assim, um verdadeiro nepotismo que não deixa de inquietar o vigário Pedro Ferreira Brandão ${ }^{20}$. Este último, à frente da ainda jovem freguesia de Sant'Anna, fundada em 1729, convida os habitantes do arraial a se reunir em associações religiosas (irmandades ou confrarias), "único meio de civilizar as almas, de lutar contra a opressão do capitão-mor Bartolomeu Bueno da Silva e de evitar o contrabando do ouro ${ }^{21 "}$.

Exatamente com esta intenção é que foi fundada, em 1733, a irmandade São Miguel e Almas, oportunamente colocada sob a proteção do arcanjo São Miguel, chefe das milícias celestes. Os homens livres (e brancos) do arraial se organizam, em sua maioria, por meio desta associação de assistência e solidariedade, "com o propósito de recorrer ao poderoso São 
Miguel, chefe das milícias celestes, a fim de que ele os livrasse das arbitrariedades cometidas pelos prepotentes daquela terra ${ }^{22 " . ~ D o t a d a ~ d e ~ u m a ~ e s t r u t u r a ~ h i e r a ́ r q u i c a ~ m a r c a n t e, ~ e s t a ~}$ confraria tinha a pretensão de aproveitar-se das configurações ainda incertas dos primeiros tempos do arraial para propor um modelo de organização social paralelo àquele que pretendia impor Bartolomeu Bueno. Propondo a solidariedade entre seus membros, organizando meios de ajuda aos menos favorecidos, ela se encarregava, igualmente, do culto de São Miguel, reivindicando para isso um altar lateral na capela a ele dedicada. Ela assumiu, de outra parte, os termos do compromisso realizado com o bispado do Rio de Janeiro (enquanto esperava a aprovação pela Coroa), a organizar anualmente, em honra a São Miguel, uma grande procissão pelas ruas do arraial ${ }^{23}$. Mas esta procissão não era a única: aconteciam outras, ao longo do ano, quando da morte de um irmão ou de uma pessoa pela qual a irmandade desejava testemunhar sua solidariedade. Após o aviso oficial do provedor às autoridades locais, os membros da confraria acompanhavam o caixão do morto "pelas ruas, avisando sua passagem pelo soar um sino ${ }^{24 "}$. Estas procissões ofereciam, assim, à confraria, a ocasião de uma referência sonora do espaço, promovendo uma demonstração pública de sua capacidade de delimitar o espaço sagrado do arraial.

Outras confrarias serão criadas nos anos seguintes, a exemplo da irmandade de Nossa Senhora do Rosário, fundada em 1734. Ela acolhia apenas negros escravos e visava, antes de mais nada, a manutenção de solidariedades étnicas. Mas, além disso, sua presença dá forma a um novo membro do corpo social do arraial de Sant'Anna. Uma outra capela, destinada ao uso dos militares, foi também criada nestes primeiros tempos: a capela da Boa Morte, fundada em 1736. Seria esta a demonstração de um desejo de afirmação dos militares enquanto corporação autônoma? Talvez. Mas, não nos esqueçamos, sobretudo, que o nascimento deste arraial acontece longe do controle da Coroa.

O que está em jogo nesses tempos de nascimento e nessas terras de fronteira são a definição e o controle do campo do político $^{25}$. E o inventário de possibilidades dos possíveis parece 
ainda largamente aberto. Até aqui, são dois modos de apropriação privada que estão em competição: aquele do "descobridor" e aquele da irmandade de São Miguel. E desta divisão emergem duas estruturas hierárquicas concorrentes. Bueno, tendo seus poderes conferidos pelo rei, e a irmandade, pelo bispo do Rio (à espera de confirmação real), cada qual dispondo de uma legitimidade reconhecida para aplicar medidas, tendo em vista o eficaz controle da sociedade coerção e clientelismo de um lado, assistência e solidariedade de outro. E cada um reivindica uma relação privilegiada com o sagrado: Bueno determinou a fundação da capela de Sant'Anna em suas terras, ao tempo em que a confraria coordena, na mesma capela, o culto a São Miguel e se encarrega da maior parte dos enterros. O sagrado se coloca desta forma, no centro do campo disputado do político ${ }^{26}$. Por seu intermédio, a sociedade é tomada enquanto unidade, ordem e permanência. $\mathrm{O}$ político emerge do sagrado em razão de sua capacidade em dar forma à sociedade. Eis porque, nos procedimentos de fundação dos arraiais de mineração, é frequentemente a partir da construção da capela que ocorre a partilha entre o espaço político e social. Seria, entretanto, redutor ver neste gesto uma simples submissão do urbano ao religioso. Suas nuances são muito mais vastas: elas revelam a instauração de um espaço sagrado no interior de um espaço profano - aquele das terras ainda informes dos sertões, onde pesa a presença ameaçadora dos índios. Em meio a uma natureza selvagem e bruta, o ritmo dos ofícios religiosos impõe igualmente as marcas de um tempo novo, aquele do homem civilizado. A criação de uma capela, oferecendo uma dupla filiação no espaço e no tempo, apresentase, desta forma, no centro dos procedimentos de fundação dos territórios da colônia.

\section{O tempo novo da vila}

Observando à distância as relações entre Bartolomeu Bueno e a irmandade, mas também as inúmeras confusões que 
gangrenam a vida desta região, apesar disso prestes a se transformar "num florão ${ }^{27 "}$ da colônia, o conde de Sarzedas, governador da capitania de São Paulo, decide reagir. Consciente da necessidade de instalar os poderes regulares nas Minas de Goiás, de modo a assegurar a tranquilidade de seus habitantes e permitir a retirada do imposto real sobre a extração do ouro, convoca uma junta extraordinária em 25 de abril de 1735, em São Paulo. Dois projetos são considerados: a criação de uma capitania separada de São Paulo e a instalação de duas vilas, em Meia Ponte e em Sant'Anna ${ }^{28}$. Informado a respeito, o rei envia ao Brasil seu homem de confiança, Martinho de Mendonça, para estudar a questão. Este não leva adiante o projeto de criação uma nova capitania, mas o próprio rei ordena ao governador (através de provisão com data de 11 de fevereiro de 1736) que se desloque pessoalmente até a região a fim de escolher o lugar mais adequado para fundar uma vila, procurando aquele que pareça mais adequado, que tenha água e madeira nas proximidades e seja próximo de um arraial ${ }^{29}$.

A decisão de Lisboa em fundar uma vila, como resposta à solicitação do governador, indica o quanto sua existência no Brasil colonial permite, antes de mais nada, a manifestação e a imposição de uma ordem política. Evidentemente, pode-se discutir o caráter urbano de uma vila ${ }^{30}$. Também é verdade que a dimensão demográfica das vilas é geralmente insignificante: a população branca atinge quando muito alguns milhares de habitantes. Entretanto, é no ambiente urbano das vilas que se estrutura a sociedade colonial por meio da identificação entre a nobreza e o povo. O povo da vila é composto pelos chefes de famílias organizados através das ordenanças - tropas auxiliares que podem reforçar as tropas regulares em caso de ameaças, notadamente indígenas (os Caiapós estão sempre às portas da cidade e nas proximidades da região). A nobreza da vila é constituída pelos chefes de famílias de boa reputação, economicamente independentes e proprietários de escravos (os homens bons). São eles que elegem, entre si, os oficiais municipais que vão compor o senado da câmara. 
Mas uma vila é também - e sobretudo - a base fundamental para a centralização administrativa. Ela se constitui na sede administrativa de um território mais vasto (o termo), que pode abrigar várias outras aglomerações (ranchos, arraiais...): o conjunto forma o concelho, unidade de base políticoadministrativa no universo português. No interior deste concelho, é a vila que anima o que Cláudia Damasceno Fonseca não hesita em nomear como "uma verdadeira rede urbana qualquer que seja a acepção que adotemos para esta noção polissêmica e ambígua ${ }^{31 " . ~ E s p e ́ c i e ~ d e ~ " v i l l e-s o l e i l " ~(F e r n a n d ~}$ Braudel), a vila reina quase unânime sobre um pequeno império (o concelho). Ela está, igualmente, em contato regular com a capital da capitania à qual pertence, bem como com Lisboa - os oficiais municipais podem se dirigir diretamente ao rei na busca de soluções para conflitos específicos. É na vila que se encontram os representantes da Coroa, como o ouvidor (magistrado encarregado da justiça em segunda instância), os soldados das tropas regulares e, nas regiões de mineração, o superintendente, funcionário que controla a distribuição de terras auríferas. As câmaras também são encarregadas de realizar a cobrança de impostos sobre o ouro, quer se trate do sistema de capitação (de acordo com o número de escravos de cada proprietário) ou do quinto (retirada da quinta parte do ouro fundido na Casa de Fundição). Trata-se, na verdade, de uma malha dupla que se organiza a partir de uma vila: administrativa, através da presença dos oficiais metropolitanos, coloniais e municipais; e territorial, com a organização das redes de comunicação que vinculam a vila a seu concelho e ao restante da colônia.

Em razão da importância estratégica das funções que assume a vila no espaço colonial, este título é sempre conferido pela Coroa. Apenas ela pode decidir transformar um arraial em vila ou mandar fundar uma vila ex-nihilo: no caso das Minas de Goiás, como em todas as regiões de fronteira, é exatamente a segunda solução que adota Lisboa.

Se a decisão de fundar uma vila é objeto de inúmeras precauções por parte das autoridades metropolitanas, a escolha 
do lugar de sua instalação, em razão das possibilidades de controle territorial que implica, é igualmente estratégica. Ora, Martinho de Mendonça não parece se preocupar, em suas considerações, com a situação da futura vila. Coube, então, ao governador Sarzedas a responsabilidade desta escolha geopolítica. Ele segue, então, para a região das minas, mas a morte o surpreende em 9 de agosto de 1737, no arraial de Traíras. Tudo indica que ele escolheria, de fato, o arraial de Sant'Anna. Com efeito, após ter nomeado Agostinho Pacheco Teles como ouvidor e superintendente geral das Minas de Goiás, ordenou que instalasse a vila no arraial de Sant'Anna. Da mesma forma, designou este mesmo arraial como quartel general do regimento dos dragões enviado de São Paulo com o objetivo de garantir a sua segurança, pacificar a região e controlar o transporte do ouro. Esta opção não parece ter sido unânime, posto que Pacheco Teles não hesita em escrever ao rei, em 17 de maio de 1738, alegando que a escolha do governador sobre a instalação da vila em Sant'Anna baseava-se na idéia de ser este arraial o mais antigo e o melhor estabelecido.

\section{A região das minas de Goiás no século XVIII}

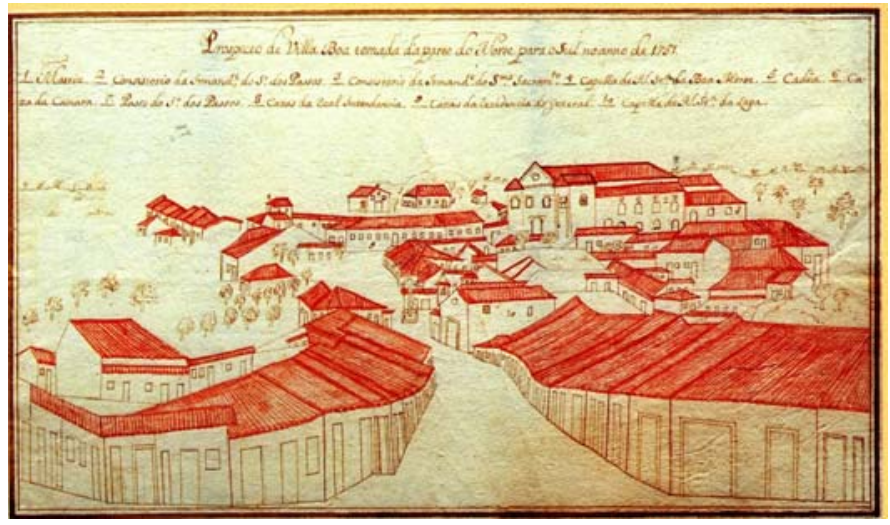

Concepção: Laurent Vidal / Realização: P. Brunello http://www.univ-lr.fr 
Ora, este argumento de anterioridade não poderia, segundo ele, ser utilizado nesta região das minas já que "nenhum deles [dos arraiais] promete ser permanente, pela facilidade com a qual seus habitantes se transportam para qualquer novo descobrimento em largas distâncias". Por isso,

bastava somente que se erija a vila que Vossa Majestade manda criar; e o lugar mais propício para ela, contra a inclinação do dito Governador Conde de Sarzedas [...] me pareceu sempre e parece o da Meia Ponte, assim por ser o clima mais saudável, e de melhores águas.

Indicado também, por estar situado numa região mais acessível a todos os habitantes das Minas ${ }^{32}$. Situado no cruzamento de caminhos que levam a São Paulo, Cuiabá e de Sant'Anna a Belém, o arraial de Meia Ponte apresenta indiscutíveis vantagens geográficas: mais que Sant'Anna, parece encarnar a ambição de centralidade da metrópole nas suas possessões coloniais. Não obstante, a argumentação de Pacheco Teles não será levada em consideração. $O$ arraial de Sant'Anna, fundado pelo inventor das Minas de Goiás, havia assumido grande importância política na região para ser ignorado. Escolher um outro arraial como sede da futura vila significaria manter de fato os poderes de Bartolomeu Bueno e de sua família. Eis porque o novo governador, dom Luís de Mascarenhas, confirma a escolha de seu predecessor.

No dia 13 de julho de 1739, acompanhado de seu secretário, Luís de Mascarenhas entra no arraial de Sant'Anna. Nomeia, então, os primeiros oficiais municipais, procurando estabelecer um equilíbrio entre metropolitanos e paulistas: Antônio Dias da Silva, originário de São Paulo, e Antônio Brito Ferreira, português fidalgo da Casa real, são nomeados juízes ordinários; o paulista Thomé Gomes Mazagão e o português Antônio Xavier Garrido são escolhidos como vereadores; João Lopes Zedes é nomeado procurador e Antônio de Brito Rabelo, escrivão da câmara. Nomeia até mesmo o porta-estandarte real: Ignácio Dias Paes, um dos genros de Bartolomeu Bueno ${ }^{33}$. Esta 
concessão à família de Bartolomeu Bueno permite confirmar o fim dos poderes extraordinários deste bandeirante sobre a região das minas: ele é nomeado, a título honorífico, capitão-mor (oficial da milícia).

Luís de Mascarenhas se dedica, em seguida, a seguir escrupulosamente as orientações precisas e pragmáticas de Lisboa $^{34}$. A fundação da vila começa pela designação do centro: a praça, sobre a qual se instalou o pelourinho, símbolo do duplo poder judiciário da comunidade e do soberano ${ }^{35}$. É no dia 25 de julho que o governador procede à instalação, determinando "que os membros do senado da câmara, com a nobreza e o povo da vila, o acompanhem com o objetivo de levantar o pelourinho, no lugar escolhido, nas proximidades do arraial, o qual, em nome do rei, deu o nome de Vila Boa ${ }^{36 " . ~ A ~ s o l e n i d a d e ~ d e s t a ~ c e n a ~}$ demonstra toda a importância do gesto. Pois fundar uma vila é buscar esquecer os erros de sua gênese, é obter uma vitória sobre o deslocamento - gesto colonial por excelência, que permitiria passar um risco sobre o passado e abrir-se para um futuro sem obstáculos ${ }^{37}$. Esta encenação permite reproduzir um ato mítico-religioso: romper o espaço-tempo profano para transformá-lo em espaço-tempo sagrado. A partir desde momento, o sagrado não está mais circunscrito à única capela, como no arraial, mas a todo o conjunto da vila. Por este grande gesto, o tempo colonial pretende, assim, se sobrepor aos tempos disputados do descobridor e da irmandade.

A vila é, por outro lado, batizada com outro nome, diferente daquele do arraial, que permanece, cada vez mais, em segundo plano: eis que surge Vila Boa (em homenagem a seu fundador Bueno), que logo será Vila Boa de Goiás, nome de uma tribo de índios pacíficos da região (Guaianases ou Goiás). Quanto aos primeiros habitantes de Vila Boa, de acordo com as indicações de Martinho de Mendonça, serão aqueles do arraial mais próximo. Mas a fim de evitar todo o risco de reprodução das clivagens anteriores, o quadro espacial no interior do qual eles serão os protagonistas será novo: deverão, então, se conformar às imposições de uma ordem que emana desta nova condição. Assim, são convidados a assistir à cena de instalação do 
pelourinho, de maneira ordenada ("a nobreza e o povo"), como se, por esse simples procedimento, se pudesse negar a sociedade "anarquista" do arraial para inventar uma sociedade plenamente implantada sob a proteção da coroa portuguesa.

Nomeados os oficiais municipais, a sociedade estabelecida, noutras palavras, projetada no espaço, o governador deve, em seguida, se dedicar à instituição dos poderes no centro da vila, indicando o lugar da igreja, da municipalidade (casa da câmara e cadeia), e dos principais edifícios públicos da vila. Para testemunhar este novo tempo, o traçado das ruas (arruamento ${ }^{38}$ ) não será mais realizado apenas em função do edifício religioso, como ocorria no arraial, mas também a partir da casa da câmara e cadeia. Deste momento em diante, serão estes os dois pólos magnéticos da vila, que vão dar forma ao espaço urbano. Espaço que será, então, constituído de ruas, dispostas em "linhas retas", e de casas com fachadas uniformes. Regularidade, equilíbrio e estética, eis as novas palavras de ordem que deverão prevalecer com o nascimento da vila e a formação da sociedade que ela vai abrigar. É desta forma que o gesto da fundação confere a Vila Boa um verdadeiro estatuto de "cidade colonial" - inscrição, no espaço e no tempo, do projeto definido pela metrópole para a vila e sua região.

Desejada como cenário renovado, Vila Boa acolhe, no entanto, indivíduos cheios de história, uma história com memórias e rastros ainda vivos, inscrita sobre um espaço próximo ao arraial e conduzida pela ação das confrarias. É esta história que desejavam apagar as autoridades coloniais por meio da instalação de um tempo novo. Eis porque a anterioridade reivindicada pelos membros da irmandade, no caso da procissão, não podia ser usada a seu favor. Ela reenvia a um tempo cujo ciclo tinha chegado ao fim. E não é certamente por simples arrogância que os membros da câmara queriam pôr termo a um costume que consistia em deixar o provedor da Irmandade ir à frente da procissão. Mas para manifestar, demonstrando clara e objetivamente, a chegada do tempo novo da vila, dos quais são eles, a partir de então, os depositários e vigilantes guardiões. Nesta nova cidade, deixar prosseguir uma 
procissão organizada segundo as modalidades tradicionais seria permitir a permanência de uma ordem antiga que poderia, em última instância, contestar a nova ordem; seria, finalmente, semear os grãos da discórdia.

\section{Os dois corpos da vila}

Mas, poder-se-ia contentar com esta definição intencional da vila? Em 1742, quando se desenrolava o conflito envolvendo a procissão, havia já três anos que a vila tinha sido instituída. Este gesto, por mais simbólico que seja não lhe concede, como por um ato de magia, uma nova vida. Se ele oferece as condições de uma estabilidade populacional, a grande maioria dos homens ainda se constitui daqueles do arraial. $O$ que modifica, realmente, a fundação de uma vila, é o inventário dos poderes que este novo organismo pode exercer e produzir. É a partir de uma nova perspectiva que devemos considerar o nascimento de Vila Boa. Não se trata mais dos tempos disputados do arraial, nem do tempo homogêneo (e abstrato) do fundador, mas do tempo do nascimento da vila, tempo de turbulências, "estando o sacerdócio e o império inseparáveis no governo dos povos ${ }^{39 "}$. Em meio a conflitos, desentendimentos e negociações ${ }^{40}$, a vila procura se impor sobre este novo cenário. Pois dar corpo à vila é fundar uma base sobre a qual se assentará a coletividade, é dar corpo à sociedade. Representante (notadamente) de uma monarquia de direito divino, a vila se reveste de um corpo sagrado; lugar de concentração de diferentes poderes (municipais, coloniais e metropolitanos), ela é dotada, igualmente, de um corpo político.

\section{Estabelecer o corpo sagrado da vila}

Nas regiões de fronteira, mais que noutras áreas do espaço colonial, caminham juntos o controle dos homens e das almas. 
Assim, a construção da capela de Sant'Anna, em 1727, por Bartolomeu Bueno, teve como duplo efeito estruturar um simples acampamento em arraial e permitir a difusão da religiosidade naquele mesmo espaço. A criação de uma paróquia, dois anos mais tarde, testemunha a ambição das autoridades eclesiásticas em participar da mesma tarefa. Poderes civis e religiosos pretendem desta forma se encarregar da cristianização daqueles sertões, tendo em vista "sua transformação em territórios controlados por autoridades que tem um papel religioso, mas também civil ${ }^{41}$ ". A instauração de uma vila modifica os termos desta competição, já que oferece a cada um dos protagonistas uma grande autoridade, ao mesmo tempo institucional e territorial: a capela é transformada em igreja paroquial (igreja matriz, em 1743) e o senado da câmara se impõe como verdadeira autoridade municipal.

Este confronto se manifesta frequentemente por ocasião das festas e procissões, onde a confusão entre os poderes civil e religioso se manifesta claramente. Com efeito, no sistema colonial português, a organização das festas públicas e das procissões reais aparece entre as atribuições das câmaras. Com a aproximação de uma festa, o senado da câmara anuncia em todo o concelho a data do evento, punindo com multa, e até mesmo com prisão, todo habitante, residente a menos de uma légua da vila, que não participasse da cerimônia ${ }^{42}$. O senado também se encarrega das despesas com a organização: entre elas, objeto de polêmicas incessantes, figura a compra de cera (velas) junto à Igreja. Sua quantidade, diferente em cada procissão, é estipulada nas Constituições primeiras do arcebispado da Bahia ${ }^{43}$. Ora, por medida de economia, não é raro que o senado adquira apenas algumas poucas velas, provocando a ira do vigário. Assim, em 1748, o ouvidor de Vila Boa solicita autorização para expor o santo sacramento por ocasião da festa de Nossa Senhora da Conceição. O padre João Perestello de Vasconcelos Spindola recusa-se a atender à solicitação do ouvidor, alegando que os oficiais de justiça, reunidos na irmandade dos Passos, não colocaram a quantidade de velas necessárias sobre o altar, como determina as constituiçõe ${ }^{44}$. O 
pagamento dos sermões e outros ofícios pastorais ligados à procissão são também objetos de controvérsias frequentes. Em 1750, por exemplo, os oficiais do senado reclamavam ao rei sobre a exigência que fazia o vigário de uma esmola no valor de 50.000 réis para a realização de uma missa cantada antes da partida da procissão de Corpus Christi ${ }^{45}$.

A frequência destas procissões reais impôs a dominação da vila no âmbito de seu território: é ela quem determina o calendário (dias feriados) e, para as festas maiores, exige a participação de toda a população do concelho. De caráter essencialmente religioso e de natureza urbana, elas têm uma dupla função de festividade: para a glorificação de Deus (e de seus santos) e de repouso. Desta forma, imprimem seu ritmo à vida social da vila. Em 1742, quatro festas reais foram programadas em Vila Boa (Corpus Christi, Anjo Custódio, Santa Isabel e São Sebastião), além daquela organizada em homenagem a Santa Ana, a patrona da vila ${ }^{46}$. Permitindo uma renovação periódica do laço de fidelidade dos habitantes à imagem do rei, elas são, também, ocasiões de uma representação ordenada da sociedade, não em função das corporações, como nas cidades européias, mas das irmandades ${ }^{47}$. Cada uma organiza um carro para o desfile, onde é exposta a imagem do santo que adora. Mas apenas os irmãos participam do desfile. O resto da população apenas assiste à cerimônia. Esta é a razão pela qual o senado procura definir detalhadamente o percurso da procissão pelas ruas da vila, bem como a ordem no interior do cortejo. Esta prerrogativa lhe confere um duplo poder de controle do espaço social: pela escolha das ruas e dos prédios por onde vai percorrer e cruzar a procissão e pelo ordenamento social em seu interior.

Deste ponto de vista, um desentendimento é particularmente revelador da importância que assume este percurso. Em 1782, a irmandade São Benedito (dos negros) modifica repentinamente seu trajeto dirigindo-se "a uma rua que não era do costume nem concedida na provisão", fora do percurso constituído por ruas "públicas, principais e decentes ${ }^{48}$ ". O vigário João Antunes de Noronha envia então um 
representante para explicar aos membros da confraria que precisavam fazer meia-volta em direção a "outra [rua] pública, real e do costume, para as quais tinham licença". Esclarecendo que, "conforme a tradição existente nestas minas desde o começo", a procissão segue sempre o mesmo percurso: partindo da igreja (matriz), o cortejo passa em frente ao palácio do governador, segue em direção ao largo do chafariz, passa pelo prédio da câmara, contornando-o e descendo pela Rua Direita até o Largo do Rosário, depois continua em direção à rua da Abadia, desce a rua do Carmo e retorna em direção à praça da igreja, onde é recolhido o santo sacramento. Após tão veemente advertência, os membros da confraria solicitam a intervenção do governador, mas o vigário, respondendo que "Sua Excelência não governa procissões", se refugia dentro da igreja com o santo sacramento.

O poder do senado, e este exemplo o comprova, não é, portanto, sem limites: ele deve, com frequência, promover negociações com as confrarias. Cristina de Cássia Morais apontou a existência de nada menos que dez delas em Vila Boa no século XVIII ${ }^{49}$. Entre elas, temos a irmandade dos Passos, fundada pelos oficiais de justiça, ou ainda a confraria dos Republicanos, fundada em 1742 pelos homens bons do senado da câmara e colocada sob a proteção de São Sebastião, cujo altar foi instalado no interior da casa da câmara e cadeia. No mesmo ano, é fundada a confraria do Santo Sacramento. Esta irmandade ocupa um lugar central na vida social da vila. Com efeito, na maior parte das procissões, é comum posicionar o santo sacramento à frente do cortejo, debaixo do pálio. Ora, o senado deve obter do provedor - nada menos que o próprio vigário da igreja paroquial - a autorização para utilizar o santo sacramento durante a procissão. Este último dispõe assim de um verdadeiro poder de negociação frente às autoridades municipais. Neste universo religioso dos $\operatorname{signos}^{50}$, as questões relativas à ordem e ao lugar no cortejo transformam-se em motivos de disputas e contendas ${ }^{51}$.

A procissão que traduz de forma exemplar esta oposição é a de Corpus Christi, organizada por determinação do rei, e que 
constitui a mais importante "festa real" do império ${ }^{52}$. Ela permite ao soberano se apresentar ao povo por intermédio do senado: seus membros, portando as armas reais, devem se colocar à frente do cortejo, próximos ao santo sacramento ${ }^{53}$. Mas como a procissão se forma sempre no interior da igreja, o clero procura sempre ter a última palavra: em 1742 as tensões foram tão intensas, provocando "tanto murmúrio do povo", que o senado tomou a decisão, muito rara, de cancelar a procissão, para não deixar livres as ruas da vila apenas aos membros da confraria. Alguns anos depois, em 1748, em meio a uma contenda entre os membros da irmandade do santo sacramento e os republicanos, em função da atribuição do lugar em frente ao dossel, na ausência do clero e dos cavaleiros, o senado decidiu que o lugar seria ocupado pelos "[homens] bons da República e não pela dita confraria". Entretanto, no momento da formação da procissão, estando o santo sacramento posicionado sob o pálio, o padre João Perestello de Vasconcelos Spindola tomou a frente do cortejo, seguido pelos membros da confraria. O senado finalmente cedeu à pressão, mandando "formarem duas alas atrás do pallio", mas, "não satisfeitos ainda [...] desta teima e desordem, saíram sem cera alguma", em desobediência à "ordem de Vossa Magestade de 13 de março de 1743", provocando tanto tumulto e desordem que, "em castigo de sua rebeldia", alguns dentre eles foram presos ${ }^{54}$.

Estas intrigas e negociações incessantes entre o senado que se pretende representante do rei - e o vigário representante de Deus - dizem respeito à definição e ao domínio do corpo sagrado da vila. Nenhuma cidade ou povoado da colônia escapa a este tipo de conflito. As Ordenações Filipinas mantém, é bem verdade, certa ambiguidade sobre o controle do campo do sagrado no interior das vilas, entre as competências das câmaras e da Igreja. Contudo, não sejamos precipitados a respeito desta política do meio termo, admitindo, neste ponto, uma fragilidade da coroa portuguesa. Se ela não permite uma excessiva concentração de poderes nas mãos dos oficiais municipais é, antes de tudo, por prudência. Estes últimos, principalmente nos pequenos povoados do interior, nem sempre 
estão imbuídos do respeito ao projeto colonial. Não utilizam este mesmo poder para reivindicar uma autonomia cada vez maior? Necessário, então, condenar a reação de resistência por parte do provedor da confraria? Ela impõe, oportunamente, um freio ao poderio e influência da câmara de Vila Boa, bem como às possibilidades de emancipação desta vila tão distante de Lisboa.

\section{Negociar o corpo político}

Com efeito, é sempre com certa reticência que a Coroa toma a decisão de fundar uma vila. Neste sentido, em 1736, no momento da partida do conde de Sarzedas para as Minas de Goiás, o governador do Rio, Gomes Freire de Andrade, não hesita em alertar o rei: "Ouço que o conde vai com a idéia de formar nos Tocantins a Vila e também intentar fazer algumas mais. Eu pelo que experimento - penso que quanto mais vilas erigir mais câmaras e quanto mais câmaras mais desobedientes ${ }^{55}$." O governador indica o principal risco que a criação de uma vila pode trazer: a insubordinação. Pois se a existência de uma vila permite integrar com eficiência um território ao espaço colonial e ao império português, promovendo uma continuidade entre a metrópole e suas possessões, ela favorece a formação de uma elite local e, ao mesmo tempo, sua autonomia.

Assim, em Vila Boa, são os novos ricos, enriquecidos graças ao ouro, à procura de oportunidades para afirmar sua nova condição social, que pretendem ocupar as posições de responsabilidade no âmbito municipal. Além do senado da câmara, formado por dois juizes ordinários, três vereadores e um procurador, eles podem almejar diversos outros ofícios como, por exemplo, o de escrivão ${ }^{56}$. A vila oferece igualmente outras oportunidades, como os postos de capitão ou de sargento-mor no interior das ordenanças: em 1760, o governador da capitania de Goiás informa ao rei sobre o importante número de oficiais de ordenanças em Vila $\mathrm{Boa}^{57}$. O provimento destes postos é de 
responsabilidade do governador, que usa esta prerrogativa para criar uma clientela fiel aos representantes da autoridade metropolitana na colônia. E esta prática é ainda mais importante e necessária quando a vila é nova. Eis porque o governador solicita ao rei que reconheça estas nomeações, atribuindo uma patente a estes oficiais. Esta posição lhes confere, por outro lado, o direito de portar um bastão de cerimônia durante as procissões ${ }^{58}$.

E assim, na condição de nobreza da terra ${ }^{59}$, os homens bons procuram distinções como o Hábito da Ordem de Cristo, oferecido em recompensa à quantidade de arrobas de ouro enviada à Casa de Fundição ou de uma alta função militar. Este título é, com efeito, uma distinção muito apreciada entre os notáveis do mundo português, em razão do estatuto social que confere. Como observou Antônio Manuel Hespanha, os benefícios das ordens militares constituem "um dos principais domínios de investimento simbólico da sociedade portuguesa moderna ${ }^{60 ", ~ j a ́ ~ q u e ~ d i s p e n s a m ~ o ~ f o r n e c i m e n t o ~ d e ~ p r o v a s ~ d e ~}$ pureza de sangue para ascender ao estatuto de nobre. A partir dos anos 1760, as solicitações não cessam de chegar às mãos do $\mathrm{rei}^{61}$. E tudo, para estes novos ricos em busca de reconhecimento social, é passível de ser negociado. Assim, em 1742, José da Silva Valença propõe um "acordo" ao rei: em contrapartida ao aluguel ridiculamente baixo que paga o governador de São Paulo para ocupar uma casa da qual é o proprietário, ele deseja que lhe seja atribuído o cargo de escrivão da ouvidoria geral de Goiás ${ }^{62}$. Nosso homem não estava enganado: ao solicitar um lugar na administração colonial, mesmo que municipal, alcançaria um grau mais elevado de reconhecimento social. Deste modo, no coração da vila, uma nova ordem se anuncia amparada pelos oficiais municipais, com os quais o poder metropolitano deverá negociar ${ }^{63}$.

Assim, a partir da instalação da vila, os membros do senado escrevem ao rei a fim de reivindicar as mesmas remunerações extraordinárias (propinas) que as câmaras de Vila Rica $^{64}$ e Ribeirão do Carmo, na capitania de Minas Gerais. Eles pretendem obter meios suficientes para organizar com 
magnificência as festas reais: " $E$ da nossa parte, e dos que nos hão de succeder, prometemos merecer em tudo o agrado de Vossa Majestade ${ }^{65}$." Em 1746, vão solicitar que lhes seja coletivamente atribuído o privilégio de cavaleiros, a exemplo do que foi feito para os oficiais de Vila do Carmo ${ }^{66}$.

O poder do senado sobre o espaço e sobre os homens aumenta gradativamente. E é exatamente por isso que o poder municipal deve ser contrabalançado pela ação dos poderes coloniais e metropolitanos. Tomemos o exemplo da justiça: se a câmara dispõe de um direito de justiça banal (de primeira instância), a justiça criminal (dita de segunda instância) é colocada nas mãos do ouvidor, nomeado pelo governador da capitania. Este oficial de justiça não hesita em controlar a ação dos oficiais municipais, denunciando certos abusos. Em 1757, por exemplo, o novo ouvidor, Antônio da Cunha Sotomaior, denuncia a atitude da câmara frente à multiplicação de crimes na região. No ano precedente, não foram menos de cento e dezessete as mortes por armas de fogo, "todas executadas por negros e mulatos". Se bem que o ouvidor tenha proibido a venda de armas, de pólvora e de chumbo "aos nossos inimigos", alguns as têm armazenado junto aos taverneiros e traficantes. E isto graças ao apoio da câmara, "que pouco [se] importa [pelo] bem público", já que se pronunciam a favor da liberdade da venda da pólvora. Antônio da Cunha Sotomaior afirma que não menos de vinte e cinco habitantes a comercializam em Vila Boa ${ }^{67}$. A câmara contra-ataca denunciando a visão pouco realista do ouvidor: muitos "bancos" cometem estes crimes ou "os mandam fazer pelos seus escravos ${ }^{68 "}$.

Além da administração da justiça, outras estruturas têm sua sede no interior da vila. Caso, por exemplo, do intendente das minas e da Fazenda real, nomeado pelo rei e pago pela Coroa. Encarregado do recolhimento da capitação (imposto sobre os escravos que atuam nas minas), mais tarde do quinto (imposto sobre o ouro depositado na Casa de fundição para ser fundido e transformado em barras), a partir de 1751, desfruta de uma larga autonomia de ação, prestando contas apenas ao rei. Em 1749, a criação da capitania de Goiás introduz um nível 
suplementar à arquitetura político-administrativa de Vila Boa, com a presença de um governador. Entretanto, como observa A. J. R. Russel-Wood, "domínios de jurisdição não anunciadas, mal definidas ou definidas de maneira obscura, tiveram por consequência uma diluição da autoridade em rivalidades e tensões entre indivíduos e agentes do governo ${ }^{69 " . ~ C o m o, ~ e n t a ̃ o, ~}$ surpreender-se com a existência de uma verdadeira cultura da intriga envolvendo cada gesto político no interior da vila? Não esqueçamos, por outro lado, que este clima de desconfiança entre os diferentes níveis de poder se amplia, com as suspeitas que guarda o Conselho do Ultramarino, principal instituição encarregada da definição da política ultramarina de Lisboa, com relação à fidelidade de seus vassalos nas regiões de fronteiras ${ }^{70}$.

Entre intrigas e negociações, o corpo político de Vila Boa toma forma sob o signo de um verdadeiro emaranhado de atribuições. E este fenômeno é acentuado pela distância que separa Vila Boa dos grandes centros de decisão: a capital da capitania (São Paulo, até 1749), a sede do vice-reino (Bahia depois Rio de Janeiro, a partir de 1763) e, é claro, Lisboa. A lentidão das correspondências administrativas e a espera quase interminável criam vazios que inquietam, levando os atores a antecipar respostas e a tomar decisões transitórias. Um caso é particularmente revelador destes pequenos arranjos, que reforçam ainda mais o sentimento de autonomia da vila. Logo após a morte súbita do governador da capitania de Goiás, em 13 de março de 1770, os oficiais municipais tomam a decisão de convocar à câmara "todos os homens bons da governança, oficiais militares pagos, auxiliares, e da ordenança para se assentar no modo e meyo como se havia de evitar algum tumulto e dezordem ${ }^{71}$ ". Ao todo, quarenta e seis pessoas se reuniram em assembléia naquele quinze de março. Não tendo encontrado, entre os documentos do governador, nenhuma informação sobre que providências adotar diante de tal situação, a assembléia decide se inspirar nas decisões que haviam sido tomadas "em ocasiões similares na América, na Bahia e no Rio de Janeiro". Uma junta provisória composta das três pessoas mais graduadas da vila (o ouvidor Antônio José Cabral de Almeida, o sargento- 
mor da cavalaria auxiliar, Antônio Thomas da Costa, e o capitão da companhia dos dragões, Damião José de Sá Pereira) é designada para "governar transitoriamente". A carta, exemplificada abaixo, chegou em março de 1771 a Lisboa $^{72}$. Quanto à resposta...:

Todo o nosso fim e objeto é servir a Vossa Majestade, de forma que não haja alteração alguma, nem os moradores desta capitania deixem de continuar na sua obediência como até agora, e assim o protestamos a Vossa Magestade de quem esperamos a providencia mais pronta no provimento do dito $\operatorname{cargo}^{73}$.

A leitura desta passagem do ato de instalação da junta provisória permite perceber o quanto a reunião desta assembléia é, antes de tudo, marcada pelo medo do vazio. Trata-se de assegurar a continuidade governamental: "suposto falecesse o governador não falecia o governo ${ }^{74}$." Mas, sobretudo, o vazio do poder pode promover uma crise social, capaz de ameaçar o próprio futuro da vila. Necessário lembrar esta evidência? Não existe coletividade humana sem um objeto que a funde. Em Vila Boa, o corpo sagrado é o objeto em torno do qual se constitui o corpo social; e o corpo político é o objeto em torno do qual ele se manifesta. O que procuram preservar os edis de Vila Boa, ante o vazio político provocado pela morte do governador, é a "tranqüilidade dos povos e tudo aquilo que conduz à sua felicidade", noutras palavras, a integridade e a unidade do tecido social.

Tal decisão revela, uma vez mais, a ambígua natureza política da câmara. Esta instância política local sempre à procura de uma autonomia cada vez mais larga no interior da colônia, colocando-se sempre, face à multiplicidade dos poderes que a vila abriga, como representante do rei e da monarquia ${ }^{75}$ : Foi, por outro lado, "por a iniciativa da câmara", lembra o ouvidor Antônio de Almeida, que a assembléia se reuniu ${ }^{76}$. Quanto à resolução, ela foi tomada "em nome de Vossa Majestade $^{77 "}$. Essas precauções não foram suficientes para convencer o marquês de Lavradio, vice-rei do Brasil, que 
considerou a decisão como "intempestiva", pois tomada sem ordem do rei que é "quem unicamente pode dar o poder de governar o povo a uma ou mais pessoas ${ }^{78}$." Em contrapartida, em Lisboa, o Conselho Ultramarino não apresentou nenhuma resposta quanto à legitimidade da iniciativa que, por outro lado, não tinha outro objetivo, se dermos crédito às palavras do ouvidor, senão a realização de despachos corriqueiros, e não de se apresentar como um "governo absoluto" 79 ".

\section{Habitar Vila Boa}

Com um único gesto, o governador fundou a vila nascimento. Mais lentamente, através da invenção de um gestual sagrado e a negociação de um espaço político, os primeiros ocupantes deram corpo à vila, criando as condições de sua existência enquanto comunidade: primeiros passos. Ao esclarecer esses mecanismos fundadores, lançamos luz sobre a natureza primeira da vila no Brasil moderno - projeto político, vetor de uma sociedade ordenada. Contudo, são insuficientes para informar concretamente sobre o tipo de sociedade que se instala nas malhas densas desta cena incorporada. É esta questão que tentaremos, agora, resolver. Convite a apreender a vila no curso ordinário do tempo e das coisas.

\section{A vila e seus muros}

O ritmo dos dias, em Vila Boa, é primeiramente marcado pela edificação progressiva da vila: edifícios públicos e casas brotam progressivamente da terra. Mas, além das normas anunciadas quando dos procedimentos da fundação, nenhum plano foi estabelecido para a nova vila. Distantes das intenções da Coroa, as exigências e peculiaridades locais, bem como o isolamento, impõem uma outra realidade - aquela da experimentação. Eis o caminho necessário para fazer face à 
penúria dos materiais e da mão-de-obra (artesãos) e, portanto, ao alto custo das construções. Em 1750, o governador dom Marcos de Noronha constata que a vila experimenta um ritmo de crescimento acelerado, mas dispõe apenas de três sobrados, como testemunha um surpreendente desenho de 1751, de autor desconhecido (ver gravura abaixo). Nenhuma delas, pela "indecência de sua condição", pode servir como morada para um governador. Ele também decidiu requerer quatro casas geminadas, ligando-as por meio de aberturas, para que servissem de palácio ${ }^{80}$. Pouco a pouco, de adaptação em adaptação, a vila ganha forma. Nomeado governador da capitania de Goiás em 1777, Luís da Cunha Menezes promove a pavimentação das ruas e o alinhamento das fachadas das casas, empreende a construção de pontes e de uma fonte pública, criando, até mesmo, um passeio público arborizado ${ }^{81}$.

De passagem por Goiás, em 1819, o naturalista francês Auguste de Saint-Hilaire revela com certa admiração a qualidade urbana de Vila Boa:

Contam-se nessa localidade cerca de 900 casas de argamassa e madeira, bastante altas para a região, porém pequenas, totalmente caiadas na frente e cobertas de telhas; várias dellas têm um andar além do rez-do-chão, e algumas, janellas guarnecidas de caixilhos feitos de talco; a maioria está bem conservada, e as dos principaes habitantes são regularmente mobiliadas e de um asseio rigoroso [...] existem em Villa Boa duas praças bastante importantes, que têm a forma de um triângulo irregular. Vários edifícios públicos, o palacio do governador, a casa da contadoria (Repartição de fazenda), a casa da fundição, a igreja parochial, outra igreja muito menos importante, ornam a primeira dessas duas praças que chamam terreiro do paço. A segunda, que é a maior, está localizada em uma das extremidades da Villa. A camara municipal (casa da camara) e o quartel dão para essa praça, em cujo centro há um chafariz $^{82}$.

A cidade que descreve Saint-Hilaire tem oitenta anos de existência - o tempo necessário para que tomasse forma. Eis o 
que nos permite calcular com maior precisão os distintos ritmos ligados ao nascimento de Vila Boa. Se o gesto do fundador é uma aposta no povoamento, aquele dos construtores aparece então como uma resposta ao povoamento. Do mesmo modo, se o gesto do fundador é habilmente conduzido com o objetivo de dar visibilidade a seu caráter extraordinário, aquele dos construtores permanece essencialmente anônimo, perdendo-se nos meandros do tempo ${ }^{83}$. O nascimento de Vila Boa, enquanto espaço urbanizado se inscreve, assim, nesta temporalidade lenta.



Vila Boa em 1751, vista da parte norte (Casa da Ínsua, Castendo, Portugal). A população de Vila Boa

Mas qual é realmente esta população de Vila Boa pela qual se elevam paredes e muros? Assistimos à sua instituição, o dia da fundação, vimos, em seguida, se organizar em confrarias e ordenanças, mas o que sabemos exatamente? Necessário constatar que, até os anos 1770, a realidade sociológica de Vila 
Boa nos escapa. Não sabemos quase nada daquilo que é extremamente importante conhecer, e principalmente: como se dá a passagem daquela multidão de aventureiros, que deram nascimento ao arraial de Sant'Anna, a uma cidade colonial organizada em células familiares? Estes tempos de mutação social permanecem, por enquanto, na sombra da história: o ordinário, a banalidade destes movimentos não atraiu a atenção da administração. Se não houve o rapto das Sabinas como em Roma, como se deu a chegada das primeiras mulheres? Como se constituíram as primeiras famílias? É verdade que a presença das mulheres marca a introdução da vila num tempo natural, aquele da reprodução. Ironia da história? É, exatamente, no momento de sua naturalização que a vila nos escapa. E quando nós a reencontramos, nos anos 1770, a região da qual ela é a sede administrativa possui uma sociedade que parece estabilizada, com uma população que já atinge seus oito mil habitantes.

População da freguesia de Vila Boa (1773-1804) ${ }^{84}$

\begin{tabular}{|l|l|l|l|l|l|}
\hline \multirow{2}{*}{ Anos } & \multicolumn{5}{|c|}{ Homens } \\
\cline { 3 - 6 } & Brancos & \multirow{2}{*}{ Pardos } & Negros & \multicolumn{2}{|c|}{ Dos quais } \\
\cline { 4 - 6 } & & & & Livres & Cativos \\
\hline $\mathbf{1 7 7 3}$ & 944 & 796 & 3744 & 2137 & 3347 \\
\hline $\mathbf{1 7 8 2}$ & 1239 & 1764 & 5643 & 2479 & 6311 \\
\hline $\mathbf{1 7 9 1}$ & 1253 & 1795 & 5622 & 2395 & 6272 \\
\hline $\mathbf{1 8 0 4}$ & 614 & 1213 & 3086 & 2253 & 2660 \\
\hline
\end{tabular}

\begin{tabular}{|c|c|c|c|c|c|c|}
\hline \multirow{3}{*}{ Anos } & \multicolumn{5}{|c|}{ Mulheres } & \multirow[t]{3}{*}{ Total } \\
\hline & \multirow[t]{2}{*}{ Brancas } & \multirow[t]{2}{*}{ Pardas } & \multirow[t]{2}{*}{ Negras } & \multicolumn{2}{|c|}{ Das quais } & \\
\hline & & & & Livres & Cativas & \\
\hline 1773 & 618 & 787 & 1523 & 1310 & 1618 & 8412 \\
\hline 1782 & 1050 & 1002 & 2052 & 1329 & 2790 & 13106 \\
\hline 1791 & 1026 & 1011 & 2226 & 1313 & 2950 & 12930 \\
\hline 1804 & 619 & 1414 & 2248 & 2520 & 1761 & 9194 \\
\hline
\end{tabular}


Estes indicadores testemunham que estamos, até os anos 1790, diante de uma típica sociedade mineradora: o tempo dos aventureiros passou dando dar lugar àquele dos senhores e seus escravos. Muitos destes homens brancos são provenientes do Nordeste ou da região do Rio, levados pela crise do açúcar brasileiro e atraídos pela possibilidade de investir o trabalho de seus escravos numa atividade aparentemente mais rentável. Alguns (cerca de um terço) parecem ter deixado sua família com a esperança de reencontrá-la mais tarde, após um rápido enriquecimento ${ }^{85}$. A desproporção homens/mulheres entre a população branca vai, por outro lado, explicar as dificuldades de instalação da família, no sentido católico do termo, na região ${ }^{86}$. Apesar de tudo, observado a uma escala microscópica, a sociedade que se forma em Vila Boa e seus arredores parece vir de encontro às expectativas da Coroa: uma população branca, que representa mais ou menos um quinto do total, se impõe sobre este universo composto majoritariamente por negros e mulatos. E a constituição de um povo representa um verdadeiro desafio no Brasil moderno. Sobre este assunto, Stuart Schwartz afirma que "aos olhos dos dignatários, por mais que o Brasil tivesse uma população, continuava desprovido de um povo": nesta terra "à qual faltava um povo digno dela", apenas as cidades pareciam constituir um verdadeiro povo, já que podia ser formado em torno dos "bons Portugueses ${ }^{87 "}$. A instalação de uma vila nas Minas de Goiás, não teria servido a esse objetivo, oferecendo as condições de emergência de uma sociedade estruturada em torno de um "projeto colonial"?

Tudo parece mudar no início do século XIX: é uma outra sociedade que se desenha, a de um povoado abandonado pela população branca e, na qual, o componente mulato se impõe. Com efeito, a população branca não atinge mais que $13 \%$, enquanto a população mestiça se aproxima dos 30\%. Contudo, os administradores coloniais parecem ter percebido esta mudança, já que transformam a categoria "pardos(as)" em "pardos(as) livres". De repente, parece saltar aos olhos uma nova realidade social: uma cidade mestiça toma forma. Um novo indicador vai lhes permitir compreender tal mutação: a instituição do 
casamento. Com efeito, se a porcentagem de casamentos permanece sempre mais elevada entre os brancos que entre os pardos livres, podem-se perceber, em contrapartida, em números absolutos, mais casais de pardos livres que de brancos. Desde então, é esta população livre de cor que constitui a base da nova sociedade de Vila Boa.

\section{Casamento e celibato da população da freguesia de Vila Boa} (1804)

\begin{tabular}{|c|c|c|c|c|c|c|c|}
\hline \multicolumn{3}{|c|}{ Brancos } & \multicolumn{3}{c|}{ Pardos livres } \\
\hline Casados & \multicolumn{2}{|c|}{ Solteiros } & \multicolumn{2}{c|}{ Casados } & \multicolumn{2}{c|}{ Solteiros } \\
\hline H & F & H & F & H & F & H & F \\
\hline 109 & 84 & 504 & 525 & 118 & 137 & 1090 & 1466 \\
\hline
\end{tabular}

\begin{tabular}{|c|c|c|c|c|c|c|}
\hline \multicolumn{4}{|c|}{ Negros livres } & \multicolumn{2}{c|}{ Negros } & Total \\
\cline { 1 - 4 } Casados & Solteiros & \multicolumn{2}{c|}{ Escravos } & \\
\cline { 1 - 5 } H & F & H & F & H & F & \\
\hline 25 & 28 & 388 & 571 & 2637 & 1795 & 9477 \\
\hline
\end{tabular}

Fonte: Luiz Palacin, O século do ouro em Goiás, op. cit., p. 79.

Seu surgimento não deveria, no entanto, surpreender a administração colonial. Pois é, antes de mais nada, graças ao ouro que as pessoas de cor podiam aspirar à sua liberdade. Os escravos conseguiram, certamente, conservar uma parte (certamente mínima) do ouro que tinham extraído. Por outro lado, devido à ausência de moeda corrente de prata e cobre nas Minas de Goiás, todas as transações comerciais eram realizadas utilizando-se o ouro em pó ${ }^{88}$. Mesmo as mulheres escravas, apesar de não participarem diretamente dos trabalhos de prospecção e de extração, podiam ter acesso ao ouro: elas 
preparavam e vendiam alimentos aos trabalhadores das minas. O ouro, que circulava na capitania, era como uma promessa de liberdade para todos aqueles escravos. Mas não era o único meio de acesso à liberdade: existem, também, entre os livres de cor, os filhos de casais ilegítimos, nascidos de uma relação entre um homem branco e uma mulher negra. $\mathrm{O}$ isolamento da vila, tanto quanto a promiscuidade social no interior de seus muros, favoreciam as práticas do concubinato ${ }^{89}$. E acontece com muita frequência, por conseguinte, que um homem compre a liberdade do filho, sem necessariamente reconhecê-lo ${ }^{90}$. Para Saint-Hilaire, as taxas exorbitantes cobradas pela igreja de Vila Boa para celebrar um casamento também estariam na origem da difusão do concubinato ${ }^{91}$. Assim, os anos passam, e o número de libertos e de mulatos não param de crescer. $\mathrm{E}$ quando as minas de ouro se esgotam, os aventureiros e também os proprietários de escravos começam a deixar a região, abandonando, no mais das vezes, concubinas e filhos. Isso explica porque, em 1804, a população branca se reduz a apenas 13\%, enquanto a de livres de cor atingem quase um terço dos habitantes da vila. A redução da produção do ouro ${ }^{92}$ pode não estar na origem desta mutação social, mas ela empresta-lhe, sem dúvida alguma, ainda vez mais relevo e evidência.

\section{Decadência ou naturalização da vila?}

Ora - coincidência? -, no momento em que esta mutação social acontece, aparece nas correspondências administrativas um discurso sobre a decadência das minas ${ }^{93}$, mas também da população e das cidades de Goiás. Assim, em 1776, o governador não hesita em descrever Vila Boa como uma cidade abandonada ${ }^{94}$. Quanto ao vigário João Antunes de Noronha, denuncia "os vícios, profanações e desordem da sociedade de Vila Boa ${ }^{95 " . ~ A l g u n s ~ a n o s ~ m a i s ~ t a r d e, ~ e m ~ 1781, ~ a ~ J u n t a ~ d a ~ R e a l ~}$ Fazenda da capitania de Goiás lembra "o estado de decadência em que se encontra a capitania ${ }^{96 " . ~ E m ~ 1784, ~ o ~ g o v e r n a d o r ~}$ Tristão da Cunha Meneses, confirma também "o estado 
deplorável em que se encontra a capitania de Goiás ${ }^{97 " . ~ V i n t e ~}$ anos mais tarde, em 1805, o desembargador Antônio Luís de Sousa Leal considera que este estado de decadência leva esta capitania "à ruína ${ }^{98 "}$. Que contraste, entretanto, com relação à impressão sentida por Saint-Hilaire durante sua visita em 1819: "Não succede em Villa Boa o mesmo que na capital da provincia das Minas, onde se veem ruas inteiras quase abandonadas; aqui se deixou, muito antes que em Villa Rica, de se occupar com a extracção do ouro, e o numero de casas está em proporção com o dos funccionários civis e militares, mercadores e artífices, de que esses empregados necessitam ${ }^{99}$." E continua sua descrição afirmando que "existem em Villa Boa (1819) muitas lojas bem sortidas ${ }^{100 "}$ ". Como compreender, então, diagnósticos tão categóricos e o surgimento deste discurso da decadência?

A vila, dissemos antes, foi pensada como um instrumento político a serviço de um projeto econômico - exploração do ouro. A organização da sociedade, bem como o ordenamento do espaço, é decorrente deste desenho inicial. Ora, acontece que, no último terço do século XVIII, o esgotamento das reservas auríferas toca o sino do "projeto colonial". Desta forma, o que sanciona o termo "decadência", sob a pena dos administradores da capitania é, antes de mais nada, o desaparecimento do projeto e a inadequação da vila a esta nova situação. A cidade em projeto cede progressivamente o lugar à cidade no presente, marcada pela crescente afirmação de uma sociedade em que domina o elemento mestiço (pardo). E é exatamente isso, por outro lado, que intriga a administração colonial. Pois a sociedade colonial não deixa nenhum lugar aos livres de cor, ao contrário dos escravos e dos índios. Com efeito, os escravos têm um lugar reconhecido na vila, com uma igreja (Nossa Senhora do Rosário) e uma confraria. O mesmo ocorre com os índios "pacificados": as autoridades não hesitam em enobrecer alguns, a lhes abrir as portas dos ofícios públicos, do mesmo modo que a incitar as uniões com os brancos, "proibindo que o nome infame de caboclo seja dado aos filhos ${ }^{101 "}$. Em contrapartida, nesta sociedade de castas, os pardos livres se encontram desprovidos de um espaço específico. 
E são, em primeiro lugar, os homens bons que tentam resistir à sua ascensão. Assim, em dezembro de 1785, os oficiais da câmara se opõem a que "o coronel mulato do Regimento dos mulatos" faça parte do governo interino de Goiás, em razão da "ordem régia de 27 de janeiro de 1726, que proíbe entrarem estes homens nas câmaras, para não acontecer o servirem indecorosamente cargos honoríficos; porém como eles sem embargo disto são de sua natureza orgulhosos, é indubitável querer o dito coronel disputar a sua preferência ${ }^{102}$." A hostilidade e o medo que inspiram "estes homens" são tão grandes quanto seu peso demográfico que, por sua vez, não para de crescer. Mary Karash informa que em 1798 eles representam 37,5\% da população de Vila Boa e que em 1804 quase 80\% das mulheres livres da vila são mulheres de $\operatorname{cor}^{103}$. O povo de Vila Boa não é mais composto de novos ricos e daqueles vindos de fora do arraial, nem mesmo dos "bons portugueses" vindos para ocupar os cargos administrativos, mas de mestiços, ou antes, mulatos. A "decadência" de Vila Boa denuncia, antes de tudo, uma mudança sociológica no seio da vila, que se liberta do "projeto colonial" para trilhar um caminho distante do controle do Rio ou de Lisboa. Certamente, trata-se ainda de manter todas as aparências exteriores de normalidade social. Saint-Hilaire lembra, também, que "durante o dia não se encontram senão homens pelas ruas Goyaz; mas logo que a noite chega, mulheres de todas as côres saem de suas casas e se espalham pela cidade $^{104 "}$.

Queixas e pedidos de reconhecimento de negros e mulatos livres não cessam de se acumular nas repartições da administração. Em fevereiro de 1803, os "homens pardos nacionais e habitantes da capitania de Vila Boa de Goyaz" fazem uma súplica ao rei, visando persuadi-lo de "que são os vassalos mais úteis ao Estado nesta colônia, e que muito mais seriam se nela houvesse observância das leis de Vossa Alteza". Que, em sua grande sabedoria, "habilitasse todos para qualquer emprego da sociedade civil ${ }^{105 "}$. São eles que resistiram aos ataques dos inimigos da colônia integrando as primeiras bandeiras; são eles que abriram a rota fluvial e comercial para a cidade do Grão Pará 
(Belém); são eles, ainda, os defensores das fronteiras do Mato Grosso: sua fidelidade ao rei foi sempre inquestionável. No entanto, embora tenham a capacidade e inteligência necessária para exercer estes cargos, seu acesso a eles é proibido, "pela única razão de seu defeito de cor". Estes defensores da cidade reclamam, em suma, de não possuírem o direito de cidadania. Ao final, assinam sua súplica de "Villa Boa de Santa Anna, Minas de Goyaz", reincorporando, assim, a toponímia do arraial primitivo (Sant'Anna) de maneira a se apresentar como os únicos herdeiros legítimos da história destas possessões ultramarinas. Mas seu argumento não vai prosperar. O Conselho Ultramarino, reunido em 7 de janeiro de 1804, sugere ao rei uma decisão "prudente": "As câmaras das cidades e vilas devem ser governadas pelos homens bons, e prudentes, e dos mais zelosos do bem público", sabendo-se pela "experiência que os americanos pardos, que são os suplicantes, carecem geralmente destas boas qualidades; pois os dotando a natureza de espírito vivo [são] ardilosos e sendo muito hábeis para as artes, transcendem pela sua vivacidade os limites da moderação sem a qual não pode haver governo feliz ${ }^{106 " . ~}$

Embora os "negros e mulatos constituem a maior parte da população de Goyaz ${ }^{107 ", ~ a ~ a d m i n i s t r a c ̧ a ̃ o ~ r e s i s t e ~ a t e ́ ~ o ~ f i m ~ a ̀ s ~}$ suas petições, assumindo uma posição rígida e inflexível: a defesa da regra e do modelo. É exatamente esta a utilidade do discurso da decadência: resistir à ascensão social dos pardos livres e às suas pretensões políticas. Reconhecer este entre-deux - lugar intermediário - de sua situação, admitir que buscavam uma passagem sob a máscara do colonial, corresponderia a semear a desordem e deixar uma esperança à "insurreição do possível ${ }^{108 "}$. Face à cidade em projeto, base de uma ordem que garantia a tranquilidade da colônia, a cidade real deve desaparecer.

A malha do tempo colonial, lançada sobre a vila no dia de sua fundação, apresentava entrelaçamentos finos e regulares. Pretendia canalizar os tempos disputados do arraial, a favor de um projeto de sociedade coerente e homogênea. Entretanto, o que as fontes sugerem, é uma outra leitura possível do 
surgimento de Vila Boa. De tempos em tempos, uma dissensão, uma discórdia (como os conflitos motivados pela hierarquia dos lugares na procissão) traz à superfície um ruído que não devemos ignorar. São fraturas e brechas que percorrem esta malha e fazem aflorar, aqui e ali, configurações sociais originais que, aparentemente submersas, não se deixam dominar pelo "projeto colonial". Acontecimentos menores, quase imperceptíveis, que murmuram sob a máscara do colonial e que, não obstante, anunciam a formação de novos mundos. Um desafio, um convite a apreender os ritmos distintos dos nascimentos de Vila Boa. Neste caso, é imperativo perceber a variação nas malhas do tempo: detendo-se naquela do tempo breve, remonta-se ao gesto do fundador, que institui uma sociedade dividida em funções; apropriando-se daquela dos tempos emaranhados e confusos, é a instituição complexa dos corpos da cidade que se desvela aos nossos olhos; tomando-se aquela dos tempos lentos e subterrâneos, é a gênese social da cidade que poderemos decodificar.

\section{Agradecimentos}

Gostaria de agradecer, por suas sugestões e observações, a Mickel Augeron, Thomas Calvo, Cláudia Damasceno Fonseca, Ana Maria Diaz, Charles Illouz, Cristina Cássia de Morais, Leandro Mendes Rocha e Fernando Lobo Lemes.

VIDAL, Laurent. Under the Mask of Colonial. Birth and "decadence" of a vila in modern Brazil; Vila Boa de Goias in the $18^{\text {th }}$ Century. História, v.28, n.1, p.243-288, 2009.

Abstract: This article discusses the emergence and construction of urban life in the outlying areas of modern Brazil. It is based on the case of Vila Boa, located in the heart of the mining region of Goias at the beginning of the eighteenth century. This settlement of gold-panners, founded in 1727, was elevated to the status of town in 1739, before becoming the capital of the Goias Captaincy 
in 1749. The multiplicity of periods and the gaps in between them, enable us to study the originality of the spatial and social configurations of the emerging town of Vila Boa during the eighteenth century. From the town project which tried to leave the marks of power in the public spaces, to the present day city with its organization and other aspects, as well as the expectant town waiting for decisions from the king or the viceroy, Vila Boa discovered its destiny. As the production of gold diminished, the "colonial project" lost much of its strength, and the town became somewhat half-breed - being labeled by the colonial authorities as "in decline".

Keywords: Colonial; Frontier; Town; The Powers; Society; Expectant.

\section{NOTAS}

${ }^{1}$ Texto publicado originalmente na revista Annales - Histoire, Sciences Sociales, ano 62, no. 3, pp. 577-606, maio-junho, 2007. Traduzido por Fernando Lobo Lemes (Université Paris 3/Sorbonne Nouvelle).

${ }^{2}$ Lisboa, Arquivo Histórico Ultramarino [AHU] Goiás, Cx. 2, d. 192.

${ }^{3}$ Ibid., d. 195.

${ }^{4}$ Laurent Vidal, "Les orientations récentes de la recherche sur l'histoire du Brésil urbain : éléments pour un bilan ", Histoire urbaine, 12, 2005, pp. 117-146.

5 João Fragoso, Maria Fernanda Bicalho e Maria de Fátima Silva Gouvêa (dir.), O Antigo Regime nos trópicos: a dinâmica imperial portuguesa (séculos XVI-XVIII), Rio de Janeiro, Edições Civilização Brasileira, 2001, pp. 23-24.

${ }^{6}$ Ver, por exemplo, a obra coordenada por Júnia Ferreira Furtado, Diálogos oceânicos. Minas Gerais e as novas abordagens para uma história do Império ultramarino português, Belo Horizonte, Editora UFMG, 2001.

${ }^{7}$ AHU, Goiás, Cx. 2, d. 195.

${ }^{8}$ Ibid., d. 740.

9 "Regimento dado por Rodrigues César de Menezes a Bartolomeu Bueno da Silva, em 30 de junho de 1722", em Documentos interessantes para a História e costumes de São Paulo, São Paulo, Typ. Paulista, 1895, vol. 12 , pp. 55-60. 
10 "A Bandeira do Anhanguera II segundo Silva Braga", em Zoroastro Artiaga, Contribuição para a história de Goiáz, Goiânia, Departamento Estadual de Cultura, 1947, pp. 16-23.

${ }^{11}$ Este regulamento, datado de 19 de abril de 1702, dispunha sobre as formas de divisão e exploração das minas de ouro.

${ }^{12}$ Cartas de 22 de novembro de 1725 e 7 de maio de 1726 (Marivone Matos Chaim, Os aldeamentos indígenas na Capitania de Goiás (17491811), Goiânia, Oriente, 1975, p. 23).

${ }^{13}$ A toponímia "Guayazes" é construída a partir do nome da etnia dos índios americanos Guyana, presente ao norte da capitania de São Paulo. Ele aparece pela primeira vez numa carta oficial em 1726, evocando o "sertão dos Guayazes" (Joaquim Francisco de Mattos, Os caminhos de Goiás, São Paulo, Editora Comercial Safady, 1980, p. 127).

${ }^{14}$ Luiz Palacin, Leônidas Franco Garcia e Janaína Amado, Historia de Goiás em documentos, I. Colônia, Goiânia, Ed. UFG, 1995, p. 31.

${ }^{15}$ Era desta forma que o Estado português procedia, nas regiões mineiras de novos descobertos. Para amenizar o vazio administrativo, a Coroa dotava o "descobridor" de um conjunto de poderes que the permitia controlar os homens e a produção de ouro. Mas estes poderes podiam ser retirados a qualquer instante. Com efeito, se o filão de ouro se revelasse particularmente rico, a administração colonial era então instalada, retomando aos poucos as responsabilidades do "descobridor", que conservava apenas um título honorífico.

${ }^{16}$ AHU, Goiás, Cx. 12, d. 740. Nas Minas Gerais, casos similares podem ser encontrados. Mas trata-se de um caso extremo do qual participa Bartolomeu Bueno da Silva em Pitangui, onde os portugueses foram impedidos de entrar: Cláudia Damasceno Fonseca, Des terres aux villes de l'or. Pouvoirs et territoires urbains au Minas Gerais (Brésil, XVIIIéme siècle), Paris, Fundação Calouste Gulbenkian, 2003, pp. 162-164.

${ }^{17}$ Aroldo de Azevedo, Brasil, a terra e o homem, vol. II, A vida humana, São Paulo, Cia Editora Nacional, 1970, pp. 239-243. Ver igualmente Murilo Marx, Cidade no Brasil, terra de quem?, São Paulo, Edusp-Nobel, 1991, pp. 17-30, e, do mesmo autor, "Arraiais mineiros: relendo Sylvio de Vasconcelos", Revista Barroco, 15, 1992, pp. 389-393. Como demonstrou perfeitamente Cláudia Damasceno Fonseca, para o caso de Minas Gerais (Cláudia Damasceno Fonseca, Des terres aux villes de l'or... op. cit.), este processo de estabilização da ocupação humana em torno de uma atividade mineira é relativamente clássico nas regiões auríferas no Brasil. Nos arredores imediatos de Sant'Anna, outros arraiais vão assim aparecer, por iniciativa de proprietários de 
concessões mineiras: Barra, Ferreiro e Ouro Fino são fundados entre 1727 e 1728. Mas, de todos estes arraiais visinhos, apenas o de Sant'Anna vai conseguir perenizar sua presença. Apesar de submetido à autoridade da vila de São Paulo de Piratininga, capital da capitania de São Paulo, por ter sido criado por iniciativa do descobridor das minas dos Guayazes, ocupa uma posição privilegiada em meio a este conjunto de arraiais mineiros: é em Sant'Anna que se encontram as sedes do poder administrativo e religioso. No contexto da América espanhola, a situação é, ao mesmo tempo, análoga e diferente. Por um lado, a criação de núcleos urbanos nas regiões de fronteira é mais frequente no século XVI que no XVIII, moldada por uma ação conjunta entre o Estado e a Igreja. Além disso, o adelantado passa uma capitulación juntamente com a Coroa, que a autoriza a criar cidades (e não simples pueblos) com embriões de corpos municipais. Os capitães donatários dispunham desta capacidade de fundar cidades, mas a partir da supressão deste regime, em 1549, apenas a Coroa, através de seus representantes, podiam fundar vilas ou transformar arraiais em vilas (sobre este assunto ver: Mickael Augeron e Laurent Vidal, "Creating colonial Brazil: The first donatary captaincies, or the system of especial exclusivity (1534-1549)", in B. Van Ruymbeke e L. H. Roper (Ed.), Constructing Early Modern empires: Proprietary ventures in the Atlantic world, 1500-1750, Leyde, E. J. Brill, 2006, pp. 20-53).

${ }^{18}$ A este respeito ver o recente trabalho de Cristina de Cássia Morais, "Do corpo místico do Cristo. Irmandades e confrarias na Capitania de Goiás (1736-1808)", Tese de doutoramento, Universidade de Lisboa, 2005.

${ }^{19}$ AHU, Goiás, Cx. 12, d. 740. O ouvidor é um magistrado encarregado da justiça de segunda instância; quanto ao juiz, é encarregado da justiça de primeira instância (justiça criminal).

${ }^{20}$ AHU, Goiás, Cx. 1, d. 4. Nesta carta datada de maio de 1732, o vicário denuncia os excessos cometidos por Bartolomeu Bueno, "doando as terras a seus parentes e desesperando o povo". Os habitantes do arraial de Meia Ponte promovem, assim, motins contra Bueno. Ver também Luiz Palacin, $O$ século do ouro em Goiás, Goiânia, Ed. Oriente, 1979, pp. 34-38.

${ }^{21}$ Arquivo Frei Simão Dorvi, Cidade de Goiás, Documentos Avulsos, "Ofício pedindo provisão de confirmação da Irmandade de São Miguel e Almas", 1734.

${ }^{22}$ C. de Cássia Morais, Do corpo místico de Cristo... op. cit., pp. 145-146.

${ }^{23}$ Compromisso assinado em 1738, mas assumido em 1733. Em 1742, ela obteve um reconhecimento real, o que lhe conferiu o estatuto de misericórdia (C. de Cássia Morais, Do corpo místico do Cristo..., op. cit., pp. 165 e 173). 
${ }^{24}$ Ibid., p. 174.

${ }^{25}$ Marcel Detienne, invoca, em artigo recente, as nuances que envolvem a definição e o controle do campo do político nos tempos de gênese, de nascimento (Marcel Detienne, "Doing comparative anthropology in the field of politics", Arion, 13, 3, 2006, pp. 67-85, aqui pp. 73-74).

${ }^{26}$ Ver o estudo geral de Murillo Marx, Nosso chão, do sagrado ao profano, São Paulo, Edusp, 2003, e a pesquisa específica de Caio Boschi, Os leigos e o poder. Irmandades leigas e política colonizadora em Minas Gerais, São Paulo, Ed. Ática, 1986.

${ }^{27}$ AHU, Goiás, Cx. 12, d. 740.

28 José Martins Pereira de Alencastre, Anais da província de Goiás, Goiânia, Editora da UFG, [1863] 1979, p. 56.

${ }^{29}$ AHU, Goiás, Cx. 1, d. 26.

${ }^{30}$ Em Minas Gerais, não é raro que um arraial tenha uma população maior que uma vila.

${ }^{31}$ C. Damasceno Fonseca, Des terres aux villes de l'or..., op. cit., p. 253.

${ }^{32}$ AHU, Goiás, Cx. 1, d. 60.

${ }^{33}$ J. M. Pereira de Alencastre, Anais da província de Goiás, op. cit., p. 72.

${ }^{34}$ AHU, Goiás, Cx. 1, d. 60.

${ }^{35}$ Como no mundo hispânico, este duplo poder judiciário, que simboliza

o pelourinho, não significa equivalência. $O$ poder do soberano, encarnado na figura do ouvidor (magistrado encarregado da justiça de segunda instância), é superior àquele da vila (que dispõe tão somente de um juiz ordinário ou de um juiz de fora, encarregado da justiça de primeira instância).

${ }^{36}$ J. M. Pereira de Alencastre, Anais da província de Goiás, op. cit., p. 72.

${ }^{37}$ A Espanha também não hesitou nas suas possessões do Novo Mundo, em re-fundar povoados já existentes. O caso de Buenos Aires é particularmente revelador: após sua fundação em 1536 pelo adelantado Pedro de Mendoza, ela é refundada em 1580 por Juan de Garay. Ver Francisco Solano, Ciudades hispanoamericanas y pueblos de índios, Madrid, Consejo Superior de Investigaciones Científicas, 1990; Alain Musset, Les villes nomades du Nouveau Monde, Paris, Éditions de l'EHESS, 2002; Thomas Calvo, "Le blanc manteau de l'urbanisation sur l'Amérique hispanique (1550-1600)", Perspectivas históricas, 5-6, 2000, pp. 12-62.

${ }^{38}$ Sobre a noção de arruamento, ver o artigo de Rafael Moreira, "A arte da ruação e a cidade luso-brasileira", Cadernos de pesquisa do $L A P, 37$, 2003, pp. 8-31, e o capítulo "Arruar" em Murilo Marx, Cidade no Brasil..., op. cit., pp. 95-100.

${ }^{39}$ AHU, Goiás, Cx. 33, d. 2041. 
${ }^{40}$ Inspirado nos trabalhos de Jack P. Green, Negociated authorities: Essays in colonial political and constitutionnal history, Charlottesville, University of Virginia Press, 1994, A. J. R. Russel-Wood insiste sobre a forma com a qual o conceito de "autoridades negociadas" levou a uma "reavaliação da representação local - a exemplo dos senados da câmara no império português - e da maneira pela qual os colonos conseguiam negociar as políticas e as práticas da Coroa, de modo a torná-las menos opressivas e/ou mais de acordo com suas prioridades, necessidades e práticas na sociedade colonial" ("Prefácio", in C. Daniels e M. V. Kennedy (ed.), Negociated empires. Centers and peripheries in the Americas, 1500-1800), Londres, Routledge, 2002, p. 13). Ver, igualmente, Francisco Bethencourt, "As câmaras", in F. Bethencourt e K. Chaudhuri, História da expansão portuguesa, vol. III, O Brasil na Balança do Império (1697-1808), Lisbonne, Circulo de Leitores, 1998, pp. 270-280.

${ }^{41}$ C. Damasceno Fonseca, Des terres aux villes de l'or.., op. cit., p. 82.

${ }^{42}$ Segundo as Ordenações Filipinas (1603). Citado por Emanuel de Araújo, O teatro dos vícios. Transgressão e transigência na sociedade urbana colonial, Rio de Janeiro, José Olympio, 1993, p. 130.

${ }^{43}$ Conjunto de regras fixadas durante o sínodo diocesano da Bahia (realizado entre 12 e 14 de junho de 1707), dispondo sobre a adaptação da doutrina católica do Brasil às normas do Concílio de Trento.

${ }^{44}$ AHU, Goiás, Cx. 6, d. 449.

${ }^{45}$ Ibid., d. 435.

${ }^{46}$ Ibid., Cx. 2, d. 160.

${ }^{47}$ Emanuel de Araújo, O teatro dos vícios..., op. cit., p. 130 sgg.

${ }^{48}$ AHU, Goiás, Cx. 33, d. 2041.

49 Dos Passos, São Miguel e Almas, São Benedito, Santo Antônio, Santíssimo Sacramento, Nossa Senhora da Lapa, Boa Morte, Nossa Senhora do Rosário, São José e Republicanos (C. de Cássia Morais, Do corpo místico de Cristo..., op. cit., p. 156).

50 Jean-Claude Schmitt, La raison des gestes dans l'Occident médiéval, Paris, Gallimard, 1990.

${ }^{51} \mathrm{Em}$ 1749, para resolver um conflito com o vigário que se recusava a entregar o santo sacramento para uma procissão, o senado fez soar o sino em toda a cidade para reunir o povo em assembléia a fim de deliberar sobre o caso.

${ }^{52}$ Ver sobre este assunto o estudo clássico de Charles R. Boxer, Portuguese society in the Tropics: The municipal councils of Goa, 
Macao, Bahia and Luanda, 1510-1800, Madison, The University of Wisconsin Press, 1965.

${ }^{53}$ Beatriz Catão Cruz Santos, "Unidade e diversidade através da festa de Corpus Christi", in I. Jancsó e I. Kantor (dir.), Festa: cultura e sensibilidade na América portuguesa, São Paulo, Hucitec/Edusp, 2001, vol. II, pp. 521-542, aqui p. 525.

${ }^{54}$ AHU, Goiás, Cx. 5, d. 370.

${ }^{55}$ Documentos interessantes..., op. cit., vol. 50, p. 292.

${ }^{56}$ Esta situação é muito freqüente nas vilas das regiões mineiras. A. J. R. Russell-Wood indica assim a mediocridade geral dos oficiais municipais de Vila Rica, no inicio de sua existência, o que teve por resultado uma "fragilidade crônica no número de candidatos aos cargos municipais" ("O governo local na América portuguesa: um estudo de divergência cultural", Revista de História, LV, 109, ano XXVIII, pp. 25-79).

57 AHU, Goiás, Cx. 17, d. 1022. Em Lisboa, Mendonça Furtado denunciava, por outro lado, o abuso de nomeações de oficiais nas miliciais, mas em vão: realizadas pelo governador, mas confirmadas pelo rei, estas nomeações serviam também para confirmações de apoios (J. M. Pereira de Alencastre, Anais da Província de Goiás, op. cit., p. 143).

${ }^{58}$ Os juizes (ordinários ou ouvidores) utilizam, por sua vez, uma vara.

${ }^{59}$ Ver sobre o tema, Maria Fernanda Baptista Bicalho, "As câmaras ultramarinas e o governo do Império", in J. Fragoso, M. F. Baptista Bicalho e Maria de Fátima Silva Gouvêa (dir.), O Antigo Regime nos trópicos..., op. cit., pp. 208-217.

${ }^{60}$ Antônio Manuel Hespanha, As vésperas do Leviathan. Instituições e poder político. Portugal (século XVII), Coimbra, Almedina, 1994, p. 342.

${ }^{61}$ AHU, Goiás, Cx. 11, d. 660; Cx. 24, d. 1565 a d. 1570, d. 1577 a d. 1579; Cx. 25, d. 1615, d. 1624; Cx. 26, d. 1695, d. 1701; Cx. 27, d. 1731, d. 1782, d. 1783, d. 1790; Cx. 28, d. 1846; Cx. 29, d. 1864; Cx. 30, d. 1952; Cx. 31, d. 1975.

${ }^{62}$ AHU, Goiás, Cx. 2, d. 147.

${ }^{63}$ A. J. R. Russel-Wood, insiste sobre esta capacidade de negociação das câmaras: instituir uma vila é criar um senado e, portanto, uma estrutura potencialmente capaz de negociar e obter vantagens. Por isso as vilas dispõem de uma autonomia bem superior àquela de suas homólogas da América espanhola (A. J. R. Russel-Wood, "Centers and peripheries in the Luso-Brazilian world, 1500-1800", in C. Daniels e M. V. Kennedy (ed.), Negociated empires..., op. cit., pp. 105-142, ici p. 117). 
${ }^{64}$ AHU, Goiás, Cx. 1, d. 92.

${ }^{65}$ Ibid., Cx. 2, d. 142.

${ }^{66}$ Ibid., Cx. 4, d. 311.

${ }^{67}$ Ibid., C. 14, d. 859.

${ }^{68}$ Ibid., d. 855.

${ }^{69}$ A. J. R. Russel-Wood, "Centers and peripheries...", art. cit., p. 113.

${ }^{70}$ Erik Lars Myrup, "The rule from afar: The overseas council and the making of the Brazilian West, 1642-1807", Ph. D., Yale University, 2006, p. 167. Ver também Luiz Palacin, Subversão e corrupção: um estudo da administração pombalina em Goiás, Goiânia, Editora da UFG, 1983.

${ }^{71}$ AHU, Goiás, Cx. 25, d. 1587 (ver, igualmente, ibid., d. 1585). Este caso8 foi recentemente estudado por Fernando Lobo Lemes, "A Oeste do Império - dinâmica da câmara municipal na última periferia colonial: um estudo das relações de poder nas Minas e Capitania de Goiás (1770-1804)", Dissertação de mestrado, Universidade Federal de Goiás, 2005, pp. 52-57.

${ }^{72}$ Ibid., d. 1639.

${ }^{73}$ AHU, Goiás, Cx. 25, d. 1587.

${ }^{74}$ Ibid., d. 1605.

75 Nas vilas de fronteira (Minas Gerais, Mato Grosso), muitos historiadores assinalaram esta dupla manifestação do poder metropolitano: ao mesmo tempo, o senado da câmara e a figura do governador. Uma vez mais, não é impossível que a explicação resida na suspeita que tinha o Conselho Ultramarino quanto à lealdade de seus vassalos nas regiões de fronteiras. Ver, por exemplo, E. O. Myrup, "The rule from Afar...", tese citada.

${ }^{76}$ AHU, Goiás, Cx. 25, d. 1605.

${ }^{77}$ Ibid., d. 1587.

${ }^{78}$ J. M. Pereira de Alencastre, Anais da província de Goiás, op. cit., p. 171. Se sentindo destituído de suas prerrogativas por decisão desta natureza, envia, enquanto espera a nomeação de um novo governador pelo rei, um governador interino. Antônio Carlos Furtado de Mendonça chega em 17 de agosto de 1770 em Vila Boa. A junta provisória é dissolvida, mas o capitão da companhia de dragões é preso após sua recusa em submeter-se a esta decisão.

${ }^{79}$ AHU, Goiás, Cx. 25, d. 1605.

${ }^{80}$ C. de Cássia Moraes, Do corpo místico de Cristo..., op. cit., p. 65.

${ }^{81}$ J. M. Pereira de Alencastre, Anais da província de Goiás, op. cit., p. 281. 
${ }^{82}$ Auguste de Saint-Hilaire, Viagem às nascentes do Rio São Francisco e pela provincia de Goyaz, tomo II, São Paulo, Companhia Editora Nacional, 1937, pp. 80-81.

${ }^{83}$ Apenas o acesso a rascunhos e anotações da época nos poderia permitir uma visão mais detalhada dos diferentes tipos de construções realizada nas primeiras décadas de Vila Boa. Uma vez mais, o historiador deve fazer face à escassez das fontes.

${ }^{84}$ Quadro estabelecido a partir dos seguintes documentos: AHU, Goiás, Cx. 27, d. 1762; Cx. 33, d. 2061; Cx. 38, d. 2380; Cx. 48, d. 2776. Importante ressaltar, no entanto, que os dados dos quais dispomos não permitem conhecer exatamente a população da vila, já que dizem respeito a toda a freguesia de Vila Boa.

${ }^{85}$ Ver o capítulo consagrado à família nas regiões mineiras, por Maria Beatriz Nizza da Silva, História da família no Brasil colonial, Rio de Janeiro, Nova Fronteira, 1998, pp. 87-94.

${ }^{86}$ Mary Karash, "Concubinato e casamento na capitania de Goiás", in M. B. Nizza da Silva (coord.), Sexualidade, família e religião na colonização do Brasil, Lisboa, Livros Horizonte, 2001, pp. 91-102, aqui p. 93. Ver igualmente da mesma autora, "The periphery of the periphery? Vila Boa de Goiás, 1780-1835", in C. Daniels e M. V. Kennedy (ed.), Negociated empires..., op. cit., pp. 143-169.

${ }^{87}$ Stuart Schwartz, "De la plebe au "peuple " dans le Brésil du XVIIIe siècle ", Caravelle, 84, 2005, pp. 127-146, aqui p. 132.

${ }^{88}$ AHU, Goiás, Cx. 7, d. 511 e Cx. 8, d. 584.

${ }^{89}$ A. de Saint-Hilaire insiste igualmente sobre esta situação: "Em parte alguma, talvez, haja tão pouca gente casada como nesta cidade (1819). Até o mais infimo operario, não ha ninguém que não tenha uma amante; mantêm-na na própria casa, criam junto a si os filhos nascidos dessas uniões illegitimas, da qual se envergonham tão pouco como de um laço sagrado, e si por acaso, alguém contrae matrimonio, torna-se logo objeto de mofa" (A. de Saint-Hilaire, Viagem às nascentes do Rio São Francisco..., op. cit., p. 85).

${ }^{90}$ Mary Karash, "As mulheres livres de cor no Brasil central", Revista da Sociedade Brasileira de Pesquisa Histórica, 15, 1998, pp. 3-20, aqui p. 4.

${ }^{91}$ A. de Saint-Hilaire, Viagem às nascentes do Rio São Francisco..., op. cit., p. 86.

${ }^{92} \mathrm{Em}$ 1753, as rendas do quinto em Vila Boa chegavam a 2.640 marcos de ouro, em 1763 a 1.714, em 1773 a 692, em 1782 a 582, em 1791 a 444 e em 1804 a 284 (AHU, Goiás, Cx. 47, d. 2717). 
${ }^{93}$ Laura de Mello e Souza trata desta questão da "decadência". Os desclassificados do ouro. A pobreza mineira no século XVIII, Rio de Janeiro, Edições Graal, 1986.

${ }^{94}$ L. Palacin, O século do ouro em Goiás, op. cit., p. 135.

${ }^{95}$ AHU, Goiás, Cx. 30, d. 1938.

${ }^{96}$ Ibid., Cx. 32, d. 2021.

${ }^{97}$ Ibid., Cx. 35, d. 2153.

${ }^{98}$ Ibid., Cx. 49, d. 2790.

${ }^{99}$ A. de Saint-Hilaire, Viagem às nascentes do Rio São Francisco..., op. cit., p. 80 .

${ }^{100}$ Ibid., p. 84.

${ }^{101}$ L. Palacin, O século do ouro em Goiás, op. cit., p. 88.

${ }^{102}$ AHU, Goiás, Cx. 36, d. 2195.

${ }^{103}$ Mary Karash, "As mulheres livres de cor...", art. cit., p. 9.

${ }^{104}$ A. de Saint-Hilaire, Viagem às nascentes do Rio São Francisco..., op. cit., p. 87.

${ }^{105}$ AHU, Goiás, Cx. 47, d. 2700.

${ }^{106}$ Ibid.

${ }^{107}$ A. de Saint-Hilaire, Viagem às nascentes do Rio São Francisco..., op. cit., p. 82.

${ }^{108}$ Jean Duvignaud, Le sous-texte, Paris, Actes Sud, 2005, p. 105.

Artigo recebido em 03/2009. Aprovado em 06/2009 